\title{
Determining the Concentration of Procalcitonin Using a Magnetic Particles-based Chemiluminescence Assay for the Clinical Diagnosis of Sepsis
}

\author{
Suwen QI, Qiaoliang LI, ${ }^{\dagger}$ Wei RaO, Xinyu LIU, Li YIN, and Huisheng ZhaNG \\ National-Reginoal Key Technology Engineering Laboratory for Medical Ultrasound, Guangdong Key \\ Laboratory for Biomedical Measurements and Ultrasound Imaging, Department of Biomedical Engineering, \\ School of Medicine, Shenzhen University, Shenzhen 518060, P. R. China
}

\begin{abstract}
Our objective is to develop an assay based on magnetic particles (MPs) to determine the concentration of procalcitonin (PCT) using a chemiluminescence immunoassay (CLIA). Fluorescein isothiocyanate (FITC) and $N$-(aminobutyl)- $N$ (ethylisoluminol) (ABEI) were used to label two different anti-procalcitonin (PCT) monoclonal antibodies. The labeled antibodies, the PCT antigen, and the anti-FITC antibody-coated MPs formed a double-sandwiched immunocomplex. The measured relative light units (RLUs) of ABEI in the substrate solution were directly proportional to the amount of PCT present in the samples. The proposed method was linear to $600 \mathrm{ng} / \mathrm{mL}$ with a detection limit of $0.03 \mathrm{ng} / \mathrm{mL}$. The coefficient of variation (CV) was $<5 \%$ and $<6 \%$ for the intra- and inter-assay precision, respectively. The average recoveries were between 95 and 107\%. The linearity-dilution effect gave a linear correlation coefficient of 0.9912 . This proposed assay provided an alternative method to quantitatively measure PCT in serum for the diagnosis of sepsis.
\end{abstract}

Keywords Chemiluminescence immunoassays (CLIA), procalcitonin (PCT), magnetic particles (MPs), sepsis, $N$-(aminobutyl)- $N$-(ethylisoluminol) (ABEI)

(Received May 9, 2013; Accepted June 21, 2013; Published August 10, 2013)

\section{Introduction}

Procalcitonin (PCT) is the precursor of the hormone calcitonin, and is 116 amino acids long with a molecular weight of $13 \mathrm{kDa}{ }^{1}$ Over the last several years, PCT has been identified as a biomarker that is strongly associated with cases of microbial infection. ${ }^{2,3}$ Systemic inflammatory response syndrome (SIRS) is systemic inflammation related to organ dysfunction and organ failure. ${ }^{4,5}$ Sepsis is a potentially deadly medical condition that is characterized by SIRS with a known infection or bacterial invasion into physiologically sterile tissue or body fluids. ${ }^{6,7}$ PCT levels are generally extremely low in healthy individuals, less $0.5 \mathrm{ng} / \mathrm{mL}$, but in patients with sepsis, the PCT serum level increases within $4 \mathrm{~h}$. The peak level of PCT is reached after $6 \mathrm{~h}$ and the concentration significantly increases up to $1000 \mathrm{ng} / \mathrm{mL}$ which is 2000-times the normal level., ${ }^{4}$ The PCT level will decrease within the normal range if the infection disappears. There are several biomarkers that are routinely used to detect sepsis, including the white blood cell (WBC) count, ${ }^{9-11}$ the erythrocyte sedimentation rate (ESR) and the C-reactive protein (CRP) concentration. ${ }^{12-14}$ However, it has become evident that these biomarkers are not as specific and sensitive as PCT. ${ }^{12,15}$ PCT has been formally approved by the FDA for use in hospital settings as a reliable marker to diagnose bacterial infections and

† To whom correspondence should be addressed.

E-mail: lq1_lq1_lq1@yahoo.com.cn disease severity as an indicator of sepsis. Serum PCT levels can be measured semiquantitatively using immunochromatography (BRAHMS PCT-Q, Henningsdorf, Germany). ${ }^{16,17}$ However, the imprecision and insensitivity of this analytic method have limited its widespread application. ${ }^{18}$ There are two common quantitative assays for PCT in the clinical lab. The first is the LIAISON-BRAHMS PCT immunoluminometric assay (DiaSorin, Saluggia, Italy), which uses a monoclonal antibody immobilized on the surface of a coated tube and another monoclonal antibody labeled with a luminescent acridine tracer. The second is the VIDAS BRAHMS PCT assay, which is based on the enzyme-linked fluorescent immunoassay (bioMérieux, Durham, NC), and uses alkaline phosphatase to catalyze the substrate into a fluorescent product. The former method is a solid-phase immune reaction that has a low efficiency of antigen-antibody binding; the second one uses enzyme cataluminescence which is susceptible to the effect of the reaction temperature.

Chemiluminescence immunoassay (CLIA) has been widely used for clinical diagnoses because they emit no radioactive waste products, cause no enzyme precipitation and exhibit an acceptable sensitivity and a wide dynamic range. ${ }^{19-21}$ Here, we report on a new CLIA for PCT that uses $N$-(aminobutyl)- $N$ (ethylisoluminol) (ABEI) as the luminescence substrate and magnetic particles that serve as both the solid phase and the separator in a liquid phase, offering many more active binding sites than a tube wall. Two different monoclonal antibodies are labeled with either ABEI or fluorescent-5-isothiocyanate 

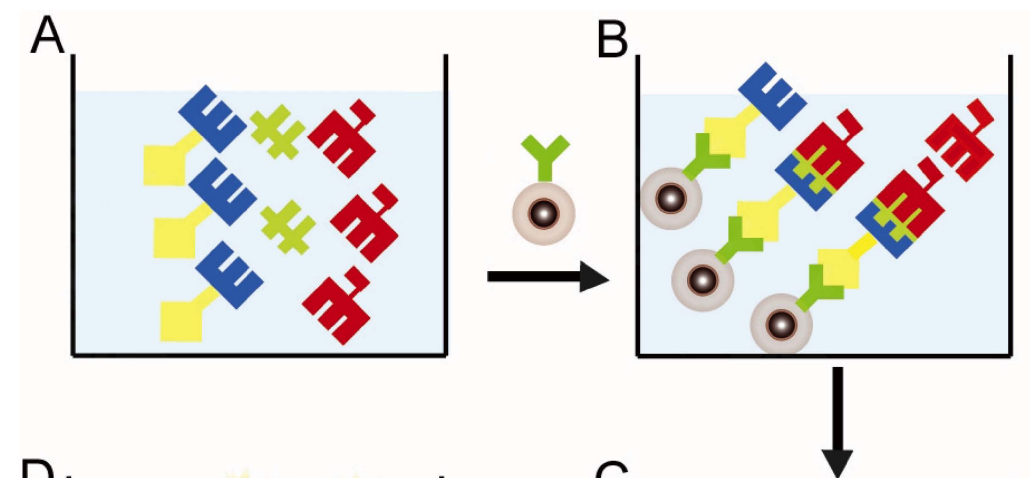
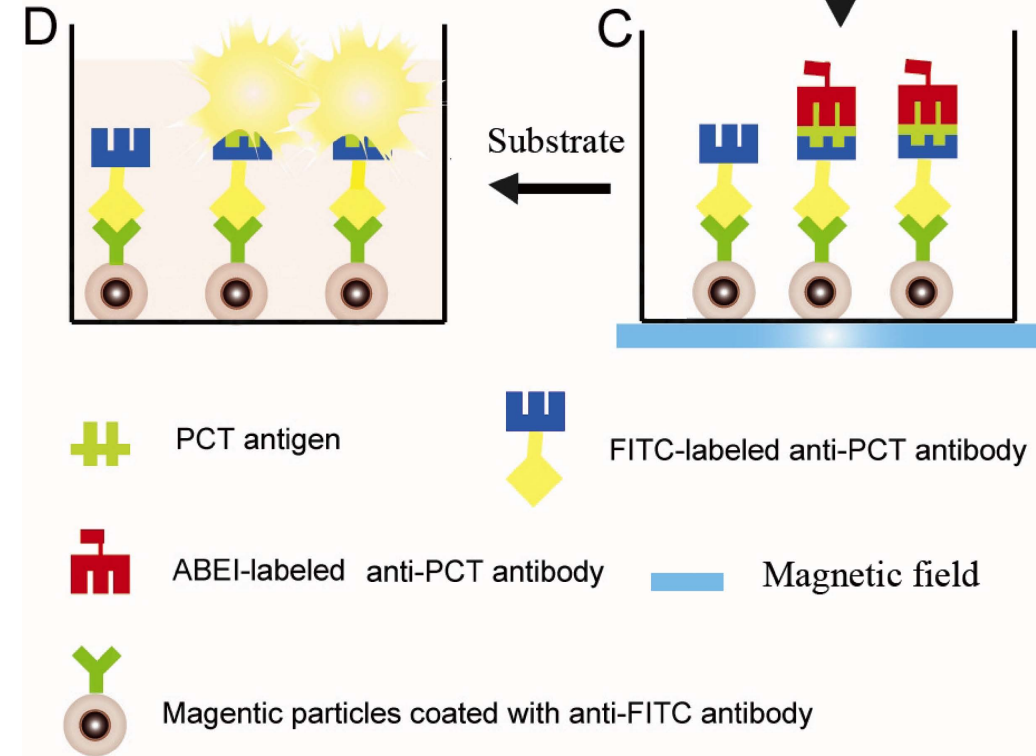

11

FITC-labeled anti-PCT antibody
ABEI-labeled anti-PCT antibody

Magnetic field

Magentic particles coated with anti-FITC antibody

Fig. 1 Schematic illustration of the proposed chemiluminescence immunoassay. (A) Immunoreaction: PCT antigen, FITC-labeled anti-PCT antibody and ABEI-labeled anti-PCT antibody were added into the tube and incubated. (B) Adding MPs: MPs coated with the goat anti-mouse FITC polyclonal antibody were added into the tube. (C) Washing and separation: adding a washing solution, unwanted materials were removed in the magnetic field. (D) Detecting PCT level: adding substrate and detecting relative light units.

(FITC). The PCT from serum combines first with the FITClabeled monoclonal antibody, and then with the magnetic particles (MPs) coated with the anti-FITC antibody. In a magnetic field, the unwanted materials are removed from PCT. The anti-ABEI antibody is then added to bind to PCT. Upon the addition of $\mathrm{NaOH}$ and $\mathrm{H}_{2} \mathrm{O}_{2}$, ABEI emits photons and forms a chemiluminescence (CL) signal. The concentration of PCT is directly related to the intensity of the CL.

In this study, the experimental conditions, including the dilution ratio of the ABEI-labeled anti-PCT antibody and FITC-labeled anti-PCT antibody, the volume of the MPs and the substrate were examined and optimized. Methodology parameters with respect to precision, detection limit and accuracy, for example, were evaluated. Our results demonstrate that this method is credible, and provides a new assay to determine PCT serum levels.

\section{Experimental}

\section{Reagents and solutions}

The PCT stock solution was purchased from Randox Life Sciences Co. (Antrim, UK). Two different monoclonal mouse anti-human PCT antibodies (ab90489 and ab166963) were obtained from Abcam Inc. (Cambridge, MA). FITC, ABEI, 1-ethyl-3-(3-dimethylaminopropyl) carbodiimide hydrochloride (EDC), $N$-hydroxysuccinimide (NHS) and sodium azide $\left(\mathrm{NaN}_{3}\right)$ were purchased from Sigma-Aldrich (St. Louis, MO). The immunomagnetic particles $(5.0 \mathrm{mg} / \mathrm{mL})$ coated with the goat anti-mouse FITC polyclonal antibody were purchased from Adaltis, Inc. (Rome, Italy). The chemiluminescent substrate ( $\mathrm{NaOH}$ and $\mathrm{H}_{2} \mathrm{O}_{2}$ ), bovine serum albumin (BSA) and dimethyl formamide were purchased from Beijing JingKeHongDa Biotech Co., Ltd. (Beijing, China). The alpha-CGRP, beta-CGRP and calcitonin proteins were purchased from US Biological Co. (Swampscott, MA).

Highly purified distilled and deionized water was used throughout the study. Solutions of $20 \%$ bovine serum and $0.1 \mathrm{~mol} / \mathrm{L}$ Tris- $\mathrm{HCl}$ buffer ( $\mathrm{pH}$ 7.6) containing $0.5 \%$ BSA were used as dilution buffers for the ABEI-labeled anti-PCT antibody and the FITC-labeled anti-PCT antibody, respectively. A carbonate buffer solution ( $\mathrm{pH}$ 9.0) and phosphate-buffered saline (PBS, pH 7.4) were used to label the anti-PCT antibodies with FITC and ABEI. A $0.05 \mathrm{~mol} / \mathrm{L}$ Tris solution containing $0.05 \%$ Tween-20 (PBST) was used as the washing buffer.

\section{Instrumentation}

A commercially available instrument, the Maglumi 2000 Plus 
automatic analyzer (New Industries Biomedical Engineering Co., Ltd., Shenzhen, China), was used for the immunoassay procedures. The incubation and shaking procedures were performed in a temperature-regulated container (FYL-YS, China) and shaker (ZXWL-100, China). A Model XW-80A vortex mixer (Jingke Industrial, Shanghai, China) was used for thorough mixing of substances.

\section{The FITC-labeled anti-PCT antibody}

The FITC-labeled anti-PCT antibody was prepared according to published methods, ${ }^{22-24}$ but with slight modifications. A $10-\mathrm{mL}$ solution of anti-PCT was adjusted to $12 \mathrm{mg} / \mathrm{mL}$ using $0.5 \mathrm{~mol} / \mathrm{L}(\mathrm{pH} 9.0) \mathrm{Na}_{2} \mathrm{CO}_{3}$ buffer and normal saline. One point three milligrams of FITC was gradually added to the anti-PCT solution over a course of approximately 5-10 min, and the solution was stirred for $12 \mathrm{~h}$ at $4^{\circ} \mathrm{C}$ in the dark. Then, the labeled anti-PCT solution was centrifuged $(2500 \mathrm{r} / \mathrm{min})$ for $20 \mathrm{~min}$ to remove a small amount of sediment, put into a dialysis bag, and then placed in a beaker of $\mathrm{pH} 9.0$ saline buffer $(0$ $4^{\circ} \mathrm{C}$ ) overnight. The protein concentration of the conjugate was measured according to the absorbance at 280 and $495 \mathrm{~nm}$. The FITC-labeled anti-PCT antibody conjugate was stored at $-20^{\circ} \mathrm{C}$ until further use.

\section{The ABEI-labeled anti-PCT antibody}

The anti-PCT antibody labeled with ABEI was prepared as previously described. ${ }^{25,26}$ Briefly, the PCT antibody was diluted

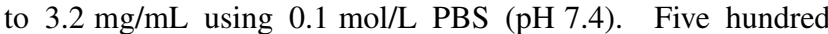
microliters containing $165 \mathrm{mg} / \mathrm{ml} \mathrm{ABEI}, 35 \mathrm{mg} / \mathrm{mL}$ NHS, and $15 \mathrm{mg} / \mathrm{mL}$ EDC was added to $500 \mu \mathrm{L}$ of the $3.2 \mathrm{mg} / \mathrm{mL}$ anti-PCT solution and incubated for $1 \mathrm{~h}$ at $37^{\circ} \mathrm{C}$. The unreacted reagents were removed via dialysis for 2 days with $0.1 \mathrm{~mol} / \mathrm{L}$ PBS (pH 7.4). The protein concentration of the conjugate was measured according to the absorbance at 280 and $495 \mathrm{~nm}$. The ABEI-labeled anti-PCT antibody conjugate was stored at $-20^{\circ} \mathrm{C}$ until further use.

\section{Calibrator preparation}

For calibration purposes, the PCT stock solution was diluted in a BSA/PBS solution $\left(0.008 \mathrm{~mol} / \mathrm{L} \mathrm{Na} \mathrm{NPO}_{4}, 0.003 \mathrm{~mol} / \mathrm{L}\right.$ $\left.\mathrm{KH}_{2} \mathrm{PO}_{4}, 0.15 \mathrm{~mol} / \mathrm{L} \mathrm{NaCl}, 10 \mathrm{~g} / \mathrm{L} \mathrm{BSA}, 0.2 \% \mathrm{NaN}_{3}, \mathrm{pH} 7.4\right)$ to reach the target concentrations of $0.00,2.00,10.00,50.00$, 300.00 and $600.00 \mathrm{ng} / \mathrm{mL}$, which were named $S_{0}, S_{1}, S_{2}, S_{3}, S_{4}$ and $\mathrm{S}_{5}$, respectively. Calibrators were divided into aliquots $(500 \mu \mathrm{L})$, and stored at $-20^{\circ} \mathrm{C}$ until further use.

\section{Immunoassay procedure}

For the immunoassay, $40 \mu \mathrm{L}$ of the PCT calibrator solution or serum samples, $100 \mu \mathrm{L}$ of the FITC-labeled anti-PCT antibody and $200 \mu \mathrm{L}$ of ABEI-labeled anti-PCT antibody were added into the tube and incubated for $10 \mathrm{~min}$ at $37^{\circ} \mathrm{C}$. Then, $20 \mu \mathrm{L}$ of MPs coated with the goat anti-mouse FITC polyclonal antibody were added into the tube. After a $10 \mathrm{~min}$ incubation period at $37^{\circ} \mathrm{C}$, unwanted materials were removed from the tubes by washing once with $400 \mu \mathrm{L}$ of a washing solution in a magnetic field. Finally, $100 \mu \mathrm{L}$ of the $\mathrm{CL}$ substrate solution $(50 \mu \mathrm{L} \mathrm{NaOH}$ and $50 \mu \mathrm{L} \mathrm{H}_{2} \mathrm{O}_{2}$ ) was added, and the relative light units (RLUs) were measured in the dark. A schematic illustration of the CLIA principle is shown in Fig. 1.

\section{Data analysis}

Calibrator and experimental samples were measured in duplicate wells, and the CL intensity values were averaged. A linear-fit standard curve was obtained by plotting the logarithm of the $\operatorname{RLU}(\log Y)$ against the logarithm of the analyte
Table 1 Effect of the FITC-anti PCT antibody concentration

\begin{tabular}{rccccc}
\hline \multirow{2}{*}{$\begin{array}{c}\text { Dilution } \\
\text { ratio }\end{array}$} & \multicolumn{5}{c}{ Relative light units (RLUs) } \\
\cline { 2 - 6 } & $\mathrm{S}_{0}$ & $\mathrm{~S}_{1}$ & $\mathrm{~S}_{5}$ & $\mathrm{~S}_{1} / \mathrm{S}_{0}$ & $\mathrm{~S}_{5} / \mathrm{S}_{0}$ \\
\hline $1 / 200$ & 1421 & 9650 & 588699 & 6.79 & 414.29 \\
$1 / 400$ & 1141 & 9074 & 548976 & 7.95 & 481.14 \\
$1 / 600$ & 1226 & 8853 & 524612 & 7.22 & 427.91 \\
$1 / 800$ & 1384 & 8214 & 485206 & 5.93 & 350.58 \\
$1 / 1000$ & 1278 & 7952 & 423578 & 6.22 & 331.44 \\
\hline
\end{tabular}

The ABEI-anti PCT antibody at a 1:200 ratio, $20 \mu \mathrm{L}$ of the anti-FITC coated MPs and $100 \mu \mathrm{L}$ of the CL substrate were incubated at $37^{\circ} \mathrm{C}$ for $10 \mathrm{~min}$. $\mathrm{S}_{0}, \mathrm{~S}_{1}, \mathrm{~S}_{5}$ were $0.00,2.00,600 \mathrm{ng} / \mathrm{mL}$ calibrator, respectively.

Table 2 Effect of the ABEI-anti PCT antibody concentration

\begin{tabular}{cccccc}
\hline \multirow{2}{*}{$\begin{array}{c}\text { Dilution } \\
\text { ratio }\end{array}$} & \multicolumn{5}{c}{ Relative light units (RLUs) } \\
\cline { 2 - 6 } & $\mathrm{S}_{0}$ & $\mathrm{~S}_{1}$ & $\mathrm{~S}_{5}$ & $\mathrm{~S}_{1} / \mathrm{S}_{0}$ & $\mathrm{~S}_{5} / \mathrm{S}_{0}$ \\
\hline $1 / 100$ & 1356 & 9201 & 523036 & 6.79 & 385.72 \\
$1 / 200$ & 1258 & 8458 & 498120 & 6.72 & 395.96 \\
$1 / 300$ & 1452 & 7914 & 352342 & 5.45 & 242.66 \\
$1 / 400$ & 1384 & 7187 & 345414 & 5.19 & 249.58 \\
$1 / 500$ & 1187 & 6007 & 302468 & 5.06 & 254.82 \\
\hline
\end{tabular}

The FITC-anti PCT antibody at a 1:400 dilution, $20 \mu \mathrm{L}$ of anti-FITC coated MPs and $100 \mu \mathrm{L}$ of the CL substrate were incubated at $37^{\circ} \mathrm{C}$ for $10 \mathrm{~min}$. $\mathrm{S}_{0}, \mathrm{~S}_{1}, \mathrm{~S}_{5}$ were $0.00,2.00,600 \mathrm{ng} / \mathrm{mL}$ calibrator, respectively.

concentration $(\log X)$. Data were analyzed with GraphPad Prism 5 (GraphPad Software, Inc., La Jolla, CA).

\section{Results}

Optimization of immunoassay reagents

As shown in Table 1, when the FITC-labeled anti-PCT antibody stock solution $(1.85 \mathrm{mg} / \mathrm{mL})$ was serially diluted from 1:200 to $1: 1000$, the corresponding RLUs decreased gradually. The linear range and sensitivity of an immunoreaction is influenced by the dilution ratio of the reagents; thus, we built a calibration curve to optimize the immunoassay reagents. The 1:400 dilution showed high sensitivity (the highest RLUS I $_{1}$ RLUS $_{0}$ ) and a wide linear range (the highest RLUS ${ }_{5} /$ RLUS $_{0}$ ). Similarly, the ABEI-labeled anti-PCT antibody stock solution $(0.36 \mathrm{mg} / \mathrm{mL})$ was serially diluted from $1: 100$ to $1: 500$, and the corresponding RLUs decreased gradually. According to the RLUS $_{1} /$ RLUS $_{0}$ and RLUS $/$ RLUS $_{0}$ values, the 1:200 dilution of ABEI-labeled anti-PCT was selected for the remaining analyses (Table 2).

\section{The influence of the volume of the magnetic particles}

The quantity of magnetic beads was critical for the analytical system. Volumes of the MPs $(5.0 \mathrm{mg} / \mathrm{mL})$ were optimized between 10 and $60 \mu \mathrm{L}$. As shown in Fig. 2, the RLUs increased as the volume of MPs increased between 10 and $20 \mu \mathrm{L}$, but as the volume of MPs was increased from 20 to $60 \mu \mathrm{L}$, the RLUs reached a plateau or decreased. Thus, a $20 \mu \mathrm{L}$ volume of MPs was chosen for further experimentation.

\section{Influence of the volume of the substrate}

The CL substrate volume was directly proportional to the CL intensity and assay sensitivity. In this experiment, the volume 


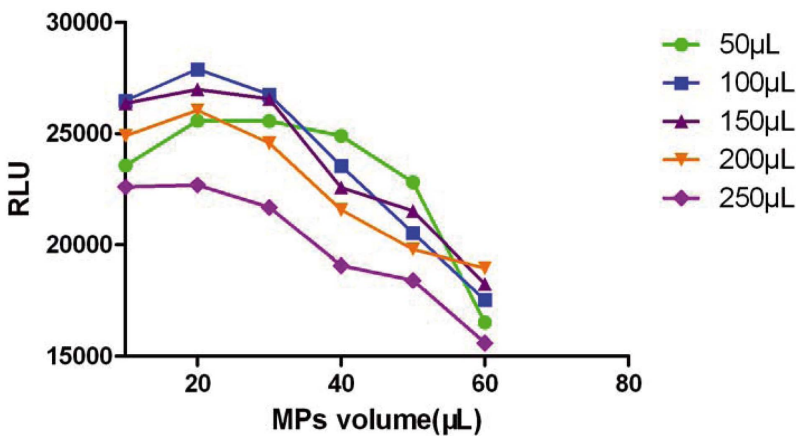

Fig. 2 Optimization of the volume of the CL substrate solution and MPs. The standard PCT concentration is $10.00 \mathrm{ng} / \mathrm{mL}$. The FITClabeled anti-PCT antibody and ABEI-labeled anti-PCT dilution ratios are 1:400 and 1:200, respectively. The reaction was incubated at $37^{\circ} \mathrm{C}$ for $10 \mathrm{~min}$. The five curves correspond to a series of substrate solution volumes $(50,100,150,200$ and $250 \mu \mathrm{L})$.

Table 3 Intra- and inter-assay variability for PCT

\begin{tabular}{|c|c|c|c|c|c|c|}
\hline \multirow[b]{2}{*}{ Sample } & \multicolumn{3}{|c|}{ Intra-assay } & \multicolumn{3}{|c|}{ Inter-assay } \\
\hline & $\begin{array}{l}\text { Time of } \\
\text { replication }\end{array}$ & $\begin{array}{c}\text { Average } \\
\text { Concentration } \\
\text { ng mL } \mathrm{mL}^{-1}\end{array}$ & $\begin{array}{c}\mathrm{CV}, \\
\%\end{array}$ & $\begin{array}{c}\text { Day of } \\
\text { replication }\end{array}$ & $\begin{array}{c}\text { Average } \\
\text { concentration/ } \\
\text { ng mL } \text { mb }^{-1}\end{array}$ & $\begin{array}{c}\mathrm{CV}, \\
\%\end{array}$ \\
\hline No. 1 & 10 & 0.45 & 4.69 & 4 & 0.47 & 5.86 \\
\hline No. 2 & 10 & 0.53 & 3.42 & 4 & 0.54 & 4.69 \\
\hline No. 3 & 10 & 10.36 & 3.21 & 4 & 10.64 & 5.56 \\
\hline
\end{tabular}

of the substrate was investigated from 50 to $200 \mu \mathrm{L}$. As shown in Fig. 2, the RLUs did not change with increasing CL substrate volumes up to $100 \mu \mathrm{L}$, and then decreased slowly with additional substrate. Therefore, we set the optimal substrate volume at $100 \mu \mathrm{L}$.

\section{Evaluation of the methodology}

Detection limit. Under the optimal conditions, a standard curve of $\log Y=0.6437 \log X+4.1247$ was obtained with a correlation coefficient of 0.9747 . The average RLU and standard deviation (SD) of the 10 replicates of $\mathrm{S}_{0}$ were 985 and 205. The sum of the average RLU and 2SD was considered as a single of the detection limit. According to the standard curve, the concentration of the detection limit was $0.03 \mathrm{ng} / \mathrm{mL}$.

Precision. Three different concentrations of serum samples were measured 10 times within one assay to evaluate the intra-assay precision. The same samples were analyzed 5 times over a period of 4 days to measure the inter-assay precision. As shown in Table 3, the coefficient of variation (CV) was $<5 \%$ and $<6 \%$ for intra- and inter-assay precision, respectively.

Recovery. The recovery test is a useful approach to check the accuracy of a method. Different amounts of PCT $(0.50,2.00$ and $30.00 \mathrm{ng} / \mathrm{mL}$ ) were added to three human sera samples to obtain different distributions; the samples were measured five times. The average recoveries (Table 4) were between 95.4 and $106.9 \%$, indicating that the results of the proposed method are satisfactory.

Linearity-dilution effect. A linearity-dilution test was performed to evaluate whether the highly concentrated samples could be accurately quantified after dilution. In this experiment, a serum sample from a patient (approximately $600 \mathrm{ng} / \mathrm{mL}$ ) was diluted by $S_{0}$ to obtain a series of concentrations, which were 1:2, 1:4,
Table 4 Recovery of PCT in human serum

\begin{tabular}{cccc}
\hline $\begin{array}{c}\text { PCT concentration } \\
\text { in human serum/ } \\
\mathrm{ng} \mathrm{mL} \mathrm{mL}^{-1}\end{array}$ & $\begin{array}{c}\text { Added amount } \\
\text { PCT/ } \\
\mathrm{ng} \mathrm{mL} \mathrm{mL}^{-1}\end{array}$ & $\begin{array}{c}\text { Mean measured } \\
\text { concentration/ } \\
\mathrm{ng} \mathrm{mL}^{-1}\end{array}$ & $\begin{array}{c}\text { Mean } \\
\text { recovery, } \\
\%\end{array}$ \\
\hline 0.53 & 0.50 & 1.02 & 99.0 \\
& 2.00 & 2.69 & 106.3 \\
1.68 & 30.00 & 31.87 & 104.4 \\
& 0.50 & 2.26 & 103.7 \\
3.34 & 2.00 & 3.51 & 95.4 \\
& 30.00 & 30.51 & 96.3 \\
& 0.50 & 3.98 & 103.6 \\
& 2.00 & 5.71 & 106.9 \\
& 30.00 & 32.05 & 96.1 \\
\hline
\end{tabular}

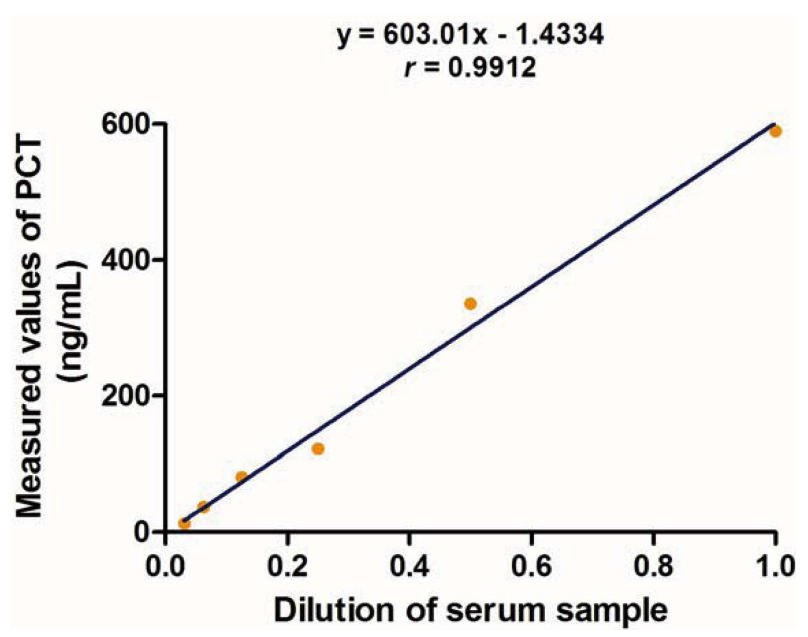

Fig. 3 Linearity-dilution effect of highly concentrated serum.

Table 5 Cross-reactivity of cross-reactants and related compounds

\begin{tabular}{lccc}
\hline Cross-reactant & $\begin{array}{c}\text { Tested } \\
\text { concentration/ } \\
\text { ng mL-1 }\end{array}$ & $\begin{array}{c}\text { PCT } \\
\text { concentration } \\
\text { determined/ } \\
\mathrm{ng} \mathrm{mL}^{-1}\end{array}$ & $\mathrm{CR}, \%$ \\
\hline Calcitonin & 15 & 0.02 & 0.13 \\
alpha-CGRP & 8500 & 2.55 & 0.03 \\
beta-CGRP & 8500 & 5.10 & 0.06 \\
\hline
\end{tabular}

1:8, 1:16 and 1:32 of the original concentration. Each sample was measured in duplicate. The relationship between the concentration of the diluted PCT and the dilution ratios had a favorable linear correlation coefficient of 0.9912 (Fig. 3).

Selectivity. The selectivity of the proposed method was evaluated by using calcitonin, alpha-CGRP and beta-CGRP, whose test concentrations were significantly higher than the normal human serum concentrations. The cross-reactivity (CR) was calculated as follows: $\mathrm{CR}=C_{(\mathrm{PCT})} / C_{\text {(cross-reactant) }} \times 100 \%$, where $C_{(\mathrm{PCT})}$ refers to the PCT concentration determined by applying the tested cross-reactant signal to the dose-response curve, and $C_{\text {(cross-reactant) }}$ refers to the cross-reactant concentration. The results showed that the CR of the PCT antibodies to crossreact with calcitonin $(15 \mathrm{ng} / \mathrm{mL})$, alpha-CGRP $(8500 \mathrm{ng} / \mathrm{mL})$ and beta-CGRP $(8500 \mathrm{ng} / \mathrm{mL})$ were $0.13,0.03$ and $0.06 \%$, respectively (Table 5). Therefore, the anti-PCT monoclonal 
antibodies used in this work were acceptable to evaluate PCT in human serum.

Comparison with another method. One hundred clinical serum samples were tested by the proposed method and VIDAS BRAHMS PCT assay. The results obtained by both methods showed good agreement with a correlation coefficient of 0.9627 .

\section{Discussion}

PCT is a known sensitive and specific biomarker of bacterial and viral infections, and is regarded as being the most helpful laboratory marker to differentiate between sepsis and SIRS. ${ }^{27-29}$ A routine rapid laboratory test for PCT has been a subject of interest in a number of studies. The objective of the present work was to develop a rapid and high-performance method to test PCT levels in human serum. The proposed assay comprised an immunological "sandwich" reaction where a FITC-labeled anti-PCT antibody, serum PCT and MPs coated with an antiFITC antibody combine. Unwanted material was washed away, and then the added ABEI-labeled anti-PCT antibody forms a MPs-immune complex. Upon adding the CL substrate, ABEI emited light, and the RLU was proportional to the level of PCT in the serum sample. An entire test can be finished in $25 \mathrm{~min}$. In the present method, the anti-PCT monoclonal antibody did not directly combine with the magnetic beads, but with FITC, which played the role of a bridge in the reaction. This design could guarantee a complete liquid-phase, and shorten the reaction time.

In the immunological "sandwich" reaction, an appropriate excess of immunoreaction reagents is important for the assay sensitivity and linear range. Therefore, the stock concentrations of the ABEI-labeled anti-PCT antibody and the FITC-labeled anti-PCT antibody were optimized. Three calibrators $\left(S_{0}, S_{1}\right.$ and $\mathrm{S}_{5}$ ) were tested to determine the optimal dilution ratios of the ABEI-labeled anti-PCT antibody and the FITC-labeled anti-PCT antibody. As displayed in Table 1, the dilution ratio of 1:400 was selected as being the optimal one for the FITC-labeled anti-PCT antibody, because it corresponded to the widest linear range (the highest RLUS $/$ RLUS $_{0}$ ) and the highest sensitivity (the highest RLUS $1 /$ RLUS $_{0}$ ). In Table 2 , the dilution ratio of 1:100 for ABEI-labeled anti-PCT shows the best sensitivity and dilution ratio of 1:200 exhibited the widest linear range. Considering the performance and reagent cost, the dilution ratio of 1:200 was selected for further research.

In this experiment, MPs were used as the separation agent. Compared to the antibodies immobilized on the surface of coated tubes, our method offers many more active binding sites for the immobilized proteins, promising an improved analytical performance. ${ }^{30}$ However, too many MPs could absorb the emitted light and decrease the sensitivity. As shown in Fig. 3, the RLUs exhibited a decreasing trend when the volume of the MPs was over $20 \mu \mathrm{L}$. Hence, we set the volume of MPs at $20 \mu \mathrm{L}$.

The methodology parameters, such as selectivity and linear range, have been evaluated carefully. PCT is the precursor of the hormone calcitonin. Two isoforms of calcitonin gene-related peptide (CGRP), alpha-CGRP and beta-CGRP, are widely expressed in serum. ${ }^{31,32}$ To study the selectivity of this assay, we tested the cross-reactivity of PCT to both isoforms of calcitonin; and our assay exhibited a little cross-reactivity, which was acceptable for the analysis. The intra- and inter-assay coefficients of variation of the present method were below 5 and $6 \%$, respectively. The accuracy of our method was examined, and exhibited recoveries ranging between 95.4 and $106.9 \%$.
The results of the linearity-dilution effect suggested that the proposed method can provided accurate quantification for samples beyond the detectable limit. Compared with the existing commercial kits, this method required less time for an entire test, and had a wider linear range.

In the present study, we used ABEI to label a PCT antibody, and established a new chemiluminescence immunoassay method that has the potential to promote the general application of PCT in the basic level hospitals and small scale laboratories.

\section{Acknowledgements}

This work was supported by the National Science Foundation of China (NSFC 61031003). The authors declare no conflict of interest.

\section{References}

1. J. W. Jacobs, P. K. Lund, J. T. Potts, Jr., N. H. Bell, and J. F. Habener, J. Biol. Chem., 1981, 256, 2803.

2. G. N. Matwiyoff, J. D. Prahl, R. J. Miller, J. J. Carmichael, D. E. Amundson, G. Seda, and M. Daheshia, Inflamm. Res., 2012, 61, 401.

3. S. Riedel, Diagn. Microbiol. Infect. Dis., 2012, 73, 221.

4. D. J. Gattas and D. J. Cook, J. Crit. Care, 2003, 18, 52.

5. N. Hofer, E. Zacharias, W. Muller, and B. Resch, J. Perinat. Med., 2012, 0,1 .

6. I. Herzum and H. Renz, Curr. Med. Chem., 2008, 15, 581.

7. M. M. Levy, M. P. Fink, J. C. Marshall, E. Abraham, D. Angus, D. Cook, J. Cohen, S. M. Opal, J. L. Vincent, and G. Ramsay, Crit. Care Med., 2003, 31, 1250.

8. K. L. Becker, R. Snider, and E. S. Nylen, Crit. Care Med., 2008, 36, 941 .

9. R. P. Dellinger, M. M. Levy, J. M. Carlet, J. Bion, M. M. Parker, R. Jaeschke, K. Reinhart, D. C. Angus, C. BrunBuisson, R. Beale, T. Calandra, J. F. Dhainaut, H. Gerlach, M. Harvey, J. J. Marini, J. Marshall, M. Ranieri, G. Ramsay, J. Sevransky, B. T. Thompson, S. Townsend, J. S. Vender, J. L. Zimmerman, and J. L. Vincent, Crit. Care Med., 2008 , 36, 296.

10. P. Singer and J. D. Cohen, Isr. Med. Assoc. J., 2011, 13, 692.

11. Z. Aminzadeh and E. Parsa, Int. J. Prev. Med., 2011, 2, 238.

12. M. Limper, M. D. de Kruif, A. J. Duits, D. P. Brandjes, and E. C. van Gorp, J. Infect., 2010, 60, 409.

13. K. M. Ho and J. Lipman, Anaesth. Intensive Care, 2009, 37, 234.

14. J. P. Caldas, S. T. Marba, M. H. Blotta, R. Calil, S. S. Morais, and R. T. Oliveira, J. Pediatr., 2008, 84, 536.

15. J. R. Fioretto, J. G. Martin, C. S. Kurokawa, M. F. Carpi, R. C. Bonatto, M. A. de Moraes, and S. M. Ricchetti, Inflamm. Res., 2010, 59, 581.

16. N. Y. Boo, A. A. Nor Azlina, and J. Rohana, Singapore Med. J., 2008, 49, 204.

17. H. Oshita, J. Sakurai, and M. Kamitsuna, J. Microbiol. Immunol. Infect., 2010, 43, 222.

18. G. Schuch, C. Duc-Marchand, C. Venet, H. Mann, A. Tixier, and C. Bionda, Ann. Biol. Clin., 2011, 69, 663.

19. A. R. Rodriguez-Orozco, H. Ruiz-Reyes, and N. MedinaSerriteno, Mini Rev. Med. Chem., 2010, 10, 1393.

20. Q. Xiao, H. Li, and J. M. Lin, Clin. Chim. Acta, 2010, 411, 1151.

21. M. Liu, Z. Lin, and J. M. Lin, Anal. Chim. Acta, 2010, 670, 1. 
22. Z. Y. Li, Q. Y. Zhang, L. X. Zhao, Z. J. Li, G. M. Hu, J. M. 28. M. Sinha, S. Desai, S. Mantri, and A. Kulkarni, Indian J. Lin, and S. Wang, Sci. China Chem., 2010, 53, 812. Anaesth., 2011, 55, 266.

23. W. Dungchai, W. Siangproh, J. M. Lin, O. Chailapakul, S. 29. K. Tschaikowsky, M. Hedwig-Geissing, G. G. Braun, and Lin, and X. Ying, Anal. Bioanal. Chem., 2007, 387, 1965.

24. V. J. Lewis, W. L. Jones, J. B. Brooks, and W. B. Cherry, Appl. Microbiol., 1964, 12, 343.

M. Radespiel-Troeger, J. Crit. Care, 2011, 26, 54.

25. M. L. Calvo-Munoz, A. Dupont-Filliard, M. Billon, S Guillerez, G. Bidan, C. Marquette, and L. Blum, Bioelectrochemistry, 2005, 66, 139.

30. H. Zhang and M. E. Meyerhoff, Anal. Chem., 2006, 78, 609.

26. D. Tian, C. Duan, W. Wang, N. Li, H. Zhang, H. Cui, and Y. Lu, Talanta, 2009, 78, 399.

27. V. Wiwanitkit, Indian J. Crit. Care Med., 2011, 15, 197.

1. Y. Frobert, M. C. Nevers, S. Amadesi, H. Volland, P. Brune, P. Geppetti, J. Grassi, and C. Creminon, Peptides, 1999, 20, 275.

32. P. Linscheid, D. Seboek, D. J. Schaer, H. Zulewski, U. Keller, and B. Muller, Crit. Care Med., 2004, 32, 1715. 